\title{
OBSERVATIONS ON THE INTERNAL STRUGTURE AND ORIGIN OF SOME FLUTES IN GLACIO-FLUVIAL SEDIMENTS, BLOMSTRANDBREEN, NORTH-WEST SPITSBERGEN
}

\author{
By M. A. Paul \\ (School of Environmental Sciences, University of East Anglia, Norwich NOR 88C, England) \\ and $\mathrm{H}$. Evans \\ (Norfolk College of Arts and Technology, King's Lynn, England)
}

\begin{abstract}
Some flutes which occur on the surface of a series of glacio-fluvial sediments at the margin of Blomstrandbreen, north-west Spitsbergen, are described. A section in one has revealed a complex internal structure, in which originally horizontal beds have been folded into an anticline whose axis is normal to the ice margin, and whose structure is related to the morphology of the flute.

Comparison of the observed deformation with the theoretical distribution of stresses around the base of a subglacial tunnel shows that this deformation could have resulted from flow under such a stress system. It is considered that these observations support the hypothesis that flutes are formed when unfrozen, watersoaked materials deform subglacially due to the pressure differences which exist in the vicinity of an ice tunnel formed in the lee of some rigid obstruction to ice flow.

Résumé. Observations sur la structure et l'origine de quelques cannelures dans les sédiments fluvio-glaciaires du Blomstrandbreen, au Nord-Ouest du Spitsbergen. On décrit quelques formes cannelées (flûtes) que l'on trouve à la surface d'une série de sédiments fluvio-glaciaires sur les bords du Blomstrandbre dans le Nord-Ouest du Spitsbergen. La section de l'une d'elles a révélé une structure interne complexe, dans laquelle les lits horizontaux originels ont été plissés sous la forme d'un anticlinal dont l'axe est perpendiculaire au bord du glacier, et la structure en relation avec la morphologie de la flûte.

La comparaison de la déformation observée avec la distribution théorique des efforts autour de la base d'un tunnel sous-glaciaire, montre que cette déformation pourrait être issue d'un tel système d'efforts. On pense que ces observations sont en faveur de l'hypothèse que les flûtes sont formées lorsque des matériels sous forme boueuse non gelée se déforment sous le glacier sous l'influence des différences de pression qui naissent au voisinage d'un tunnel de glace à l'abri de quelque obstacle rigide opposé à l'écoulement de la glace.
\end{abstract}

Zusammenfassung. Beobachtungen uber die innere Struktur und die Herkunft einiger "Flutes" in glazifluvialen Sedimenten am Blomstrandbreen, NW-Spitsbergen. Einige "Flutes" (orgelpfeifenartig angeordnete, niedrige Moränenkämme), die auf der Oberfläche einer Serie von glazifluvialen Sedimenten am Rande des Blomstrandbreen, Nordwest-Spitsbergen, auftreten, werden beschreiben. In einem Querschnitt durch einen davon zeigte sich eine komplizierte innere Struktur, bei der ursprünglich horizontale Schichten in eine Antiklinale aufgefaltet wurden, deren Achse senkrecht zum Eisrand verläuft und deren Struktur von der Morphologie des "Flute" abhängt.

Der Vergleich der beobachteten Deformation mit der theoretischen Spannungsverteilung an der Basis eines subglazialen Tunnels zeigt, dass diese Deformation das Ergebnis von Fliessvorgängen unter einem solchen Spannungssystem sein könnte. Diese Beobachtungen scheinen zur Stützung der Hypothese geeignet, dass "Flutes" dann entstehen, wenn ungefrorenes, wassergetränktes Material sich subglazial durch Druckunterschiede in der Nachbarschaft eines Tunnels verformt, der auf der Lee-Seite eines starren Hindernisses gegen den Eisfluss gebildet wird.

\section{INTRODUGTION}

Fluted lodgement-till surfaces exposed beyond the margins of modern glaciers have been described by several authors. It is commonly considered that these flutes form subglacially when differential pressure causes the till to flow into cavities or tunnels immediately beneath the glacier sole (Dyson, 1952; Hoppe and Schytt, 1953) but, since the till involved is often massive and structureless, clear evidence of flow is not usually seen.

This paper describes a situation in which flutes occur on the surface of glacio-fluvial sediment, and have an internal structure from which the style of deformation is readily apparent. In this case the structure indicates that material has flowed from an area of high pressure at the tunnel margin to areas of lower pressure both inside the tunnel and away from it. There is good agreement between the observed structure and the theoretical stress distribution around the base of the tunnel. 


\section{Field observations}

Blomstrandbreen flows southward into Kongsfjorden in north-west Spitsbergen (Fig. I). The central part of the ice front is land-based, while to the east and west the glacier terminates in the sea (Fig. 2).

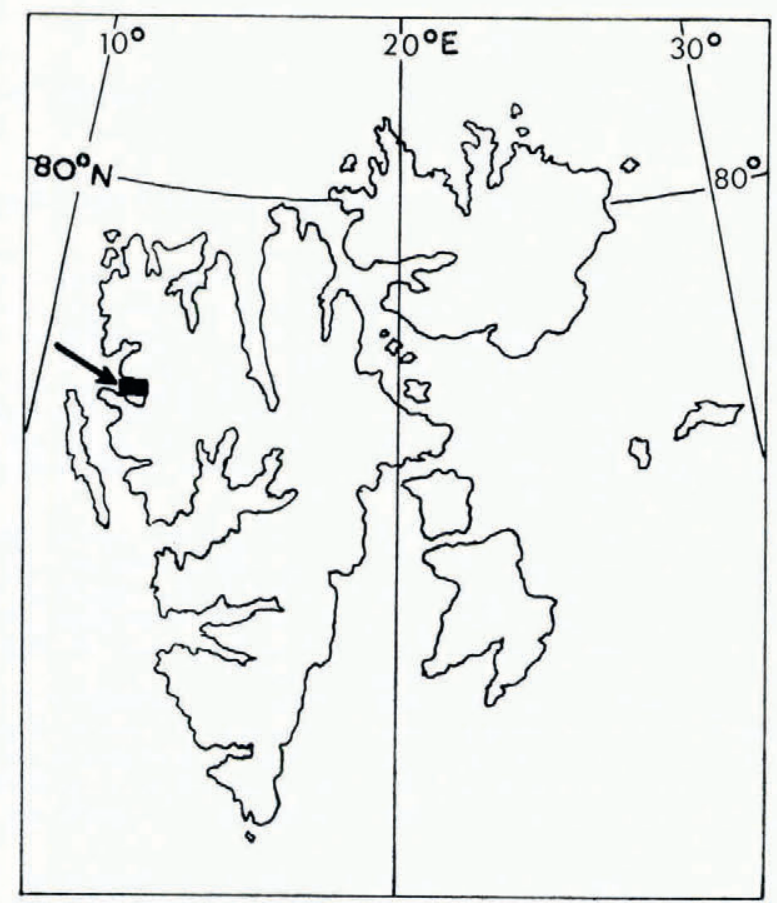

Fig. I. Location of Figure 2 in north-west Spitsbergen.

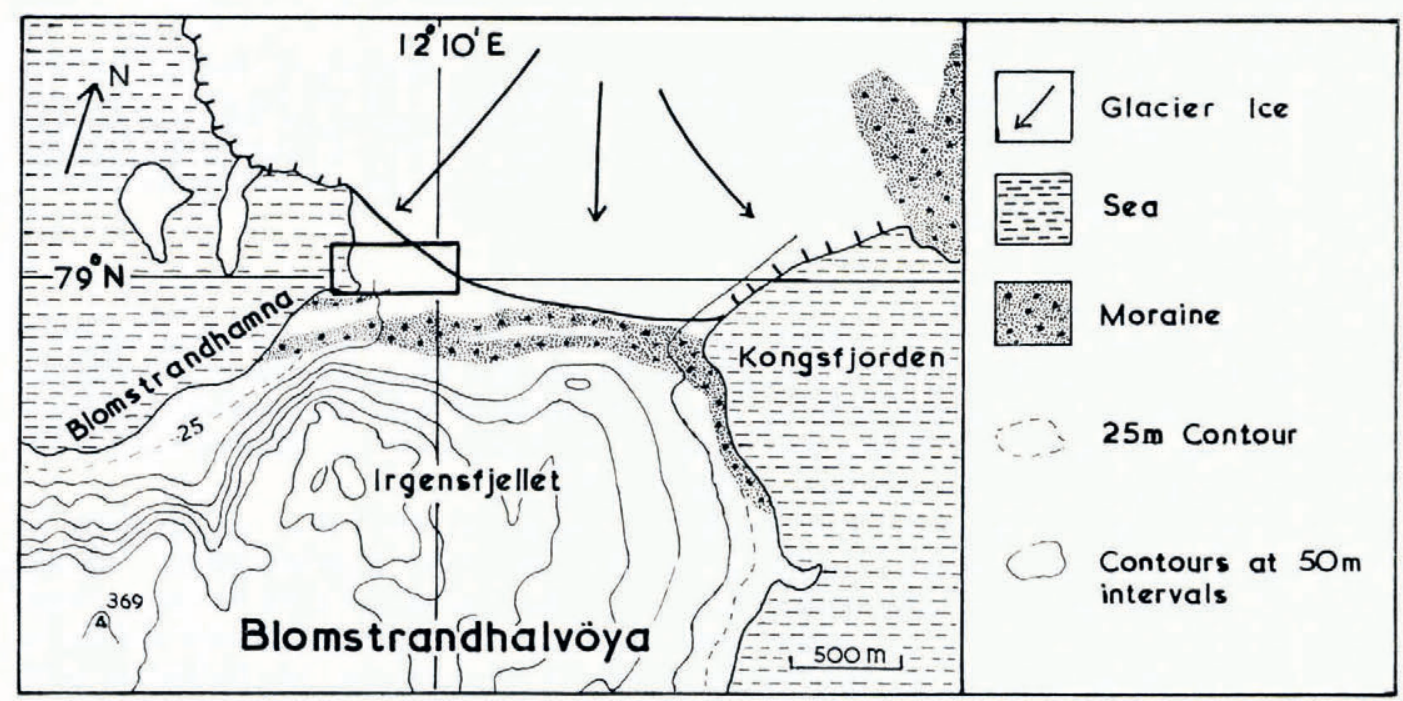

Fig. 2. Map of the ice front of Blomstrandbreen, showing its land-based margin against Blomstrandhalvöya. 
The flutes lie on an apron of sand and silt that occurs at the western end of the land-based ice front (point A in Figure 3). To the immediate west of this area are a number of bedrock knobs on which the glacier is partially resting. The flutes originate under the ice and can be traced for I I $\mathrm{m}$ into the pro-glacial area. Initially they are about $65 \mathrm{~cm}$ wide and $20 \mathrm{~cm}$ high, but they become wider and flatter with increasing distance from the ice front. They are not evenly spaced. The apron on which they lie is waterlogged, and in some places it is washed by small rivulets.

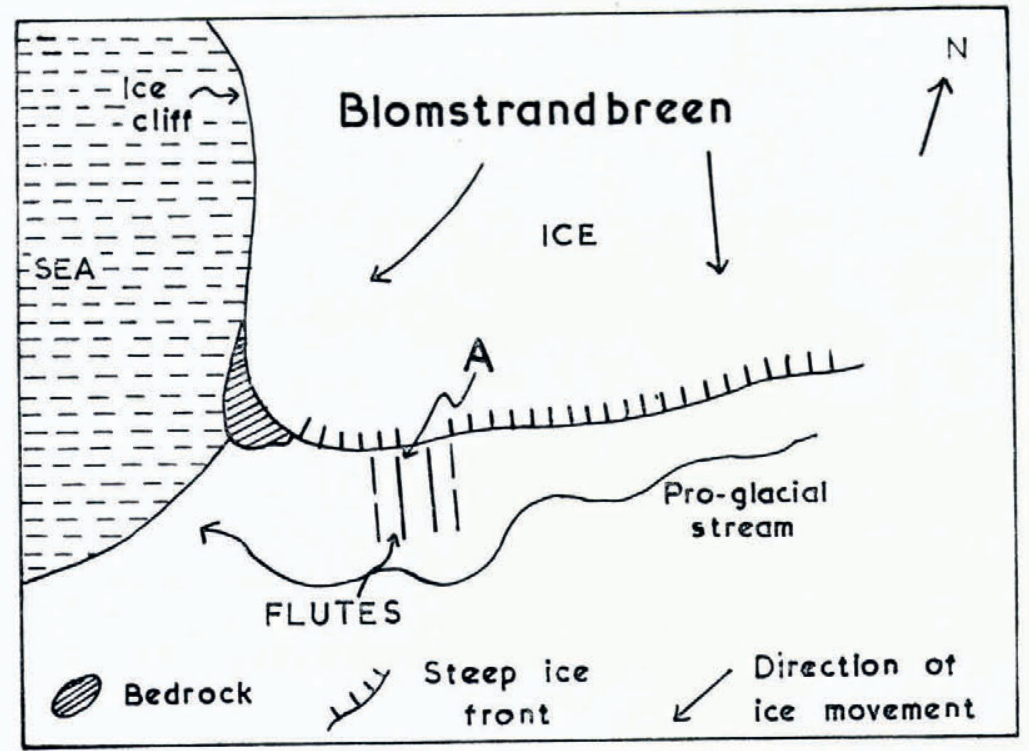

Fig. 3. The western part of the land-based margin described in the text.

A pit dug into an area on the apron away from the flutes shows $0.4 \mathrm{~m}$ of silt and fine sand resting on massive structureless till. This till, which is soft and waterlogged, was proved to a depth of $0.5 \mathrm{~m}$. The overlying silts and sands show a complicated succession in which they replace one another rapidly both horizontally and vertically, individual beds varying in thickness along their length. There are also pockets and stringers of coarse sand and fine gravel, particularly in the upper part of the sequence. The beds are horizontal with no evidence of flexuring. The sequence is closely parallelled by others in the area, and it appears characteristic of deposits laid down by glacial melt-water streams, which migrate readily and show rapid variations in discharge.

A second pit was dug across one of the flutes and on to the adjacent unfluted surface to the east (Figs. 4 and 5). The sections reveal that within the flutes considerable disturbance has affected the upper part of the sequence and that this is directly related to the morphology of the flute. To the east, below the unfluted surface, there is some further deformation.

Figure 4 shows the section below the unfluted surface. In the lower part of the sequence there is no disturbance, but in the upper part beds of coarse and fine sand are folded into a very broad anticline, which is asymmetric, with the steep limb to the east. This structure is truncated by the uppermost bed which appears undisturbed. These beds are also thickest to the east and they thin westward.

The section through the flute itself is shown in Figures 5 and $6 \mathrm{a}$. The main structure is an overturned anticline, closing to the west, and whose lower limb is truncated by a thrust plane. This plane dips eastward at $30^{\circ}$ and is marked by a line of sheared-out wisps of sand 


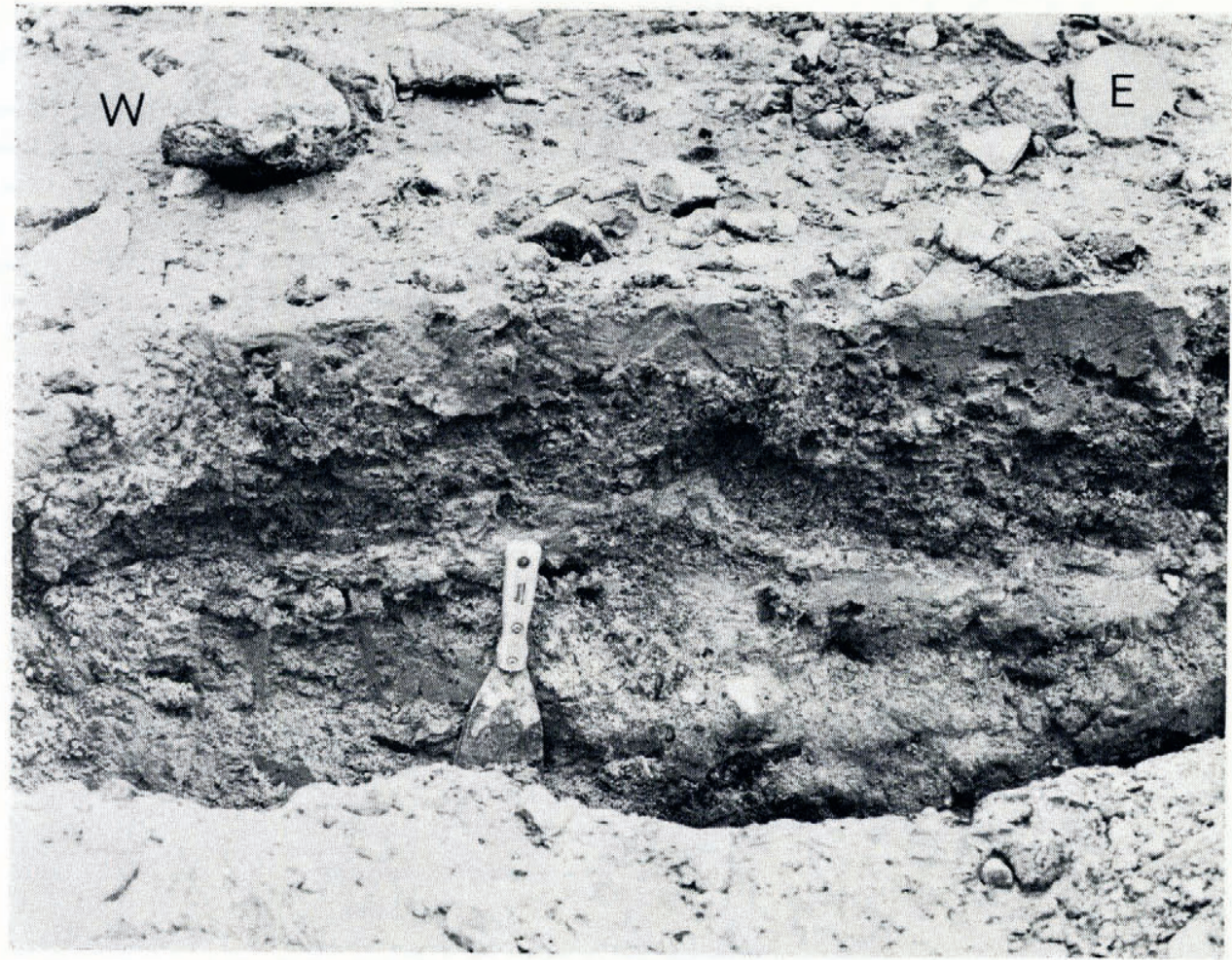

Fig. 4. A pit dug in the flat surface to the east of the flute illustrated in Figure 5. The section reveals folding in the underlying beds, in a direction trending away from the flute itself, which lies to the left just outside the photograph.

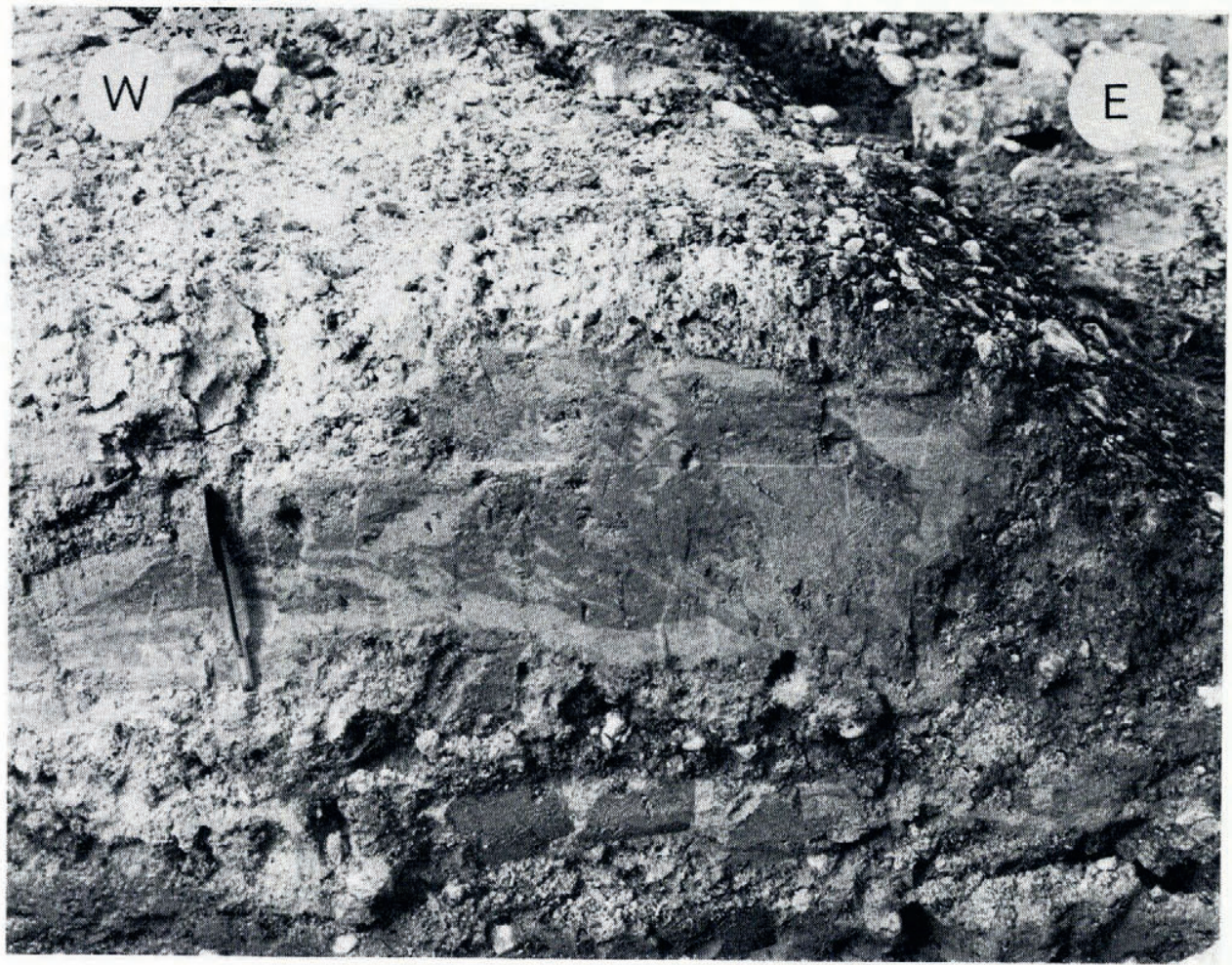

Fig. 5. The section in the flute, showing a major overturned anticlinal fold in the body of the flute. The scale is I4 cm high. 
and silt. The central part of the flute above this thrust plane shows considerable structural complexity, which is essentially due to a large number of tight, sub-parallel overturned folds on the limbs of the main structure, some of which are sheared out or cut by small thrusts. These folds also close westward and have axial planes striking parallel to the axis of the flute. There is a systematic change in the dips of these axial planes. In the core of the flute they are parallel to the thrust plane and also to the axial plane of the gross anticlinal structure. In the crest of the flute, however, dips reduce to $10-15{ }^{\circ}$, indicating a flattening of the fold

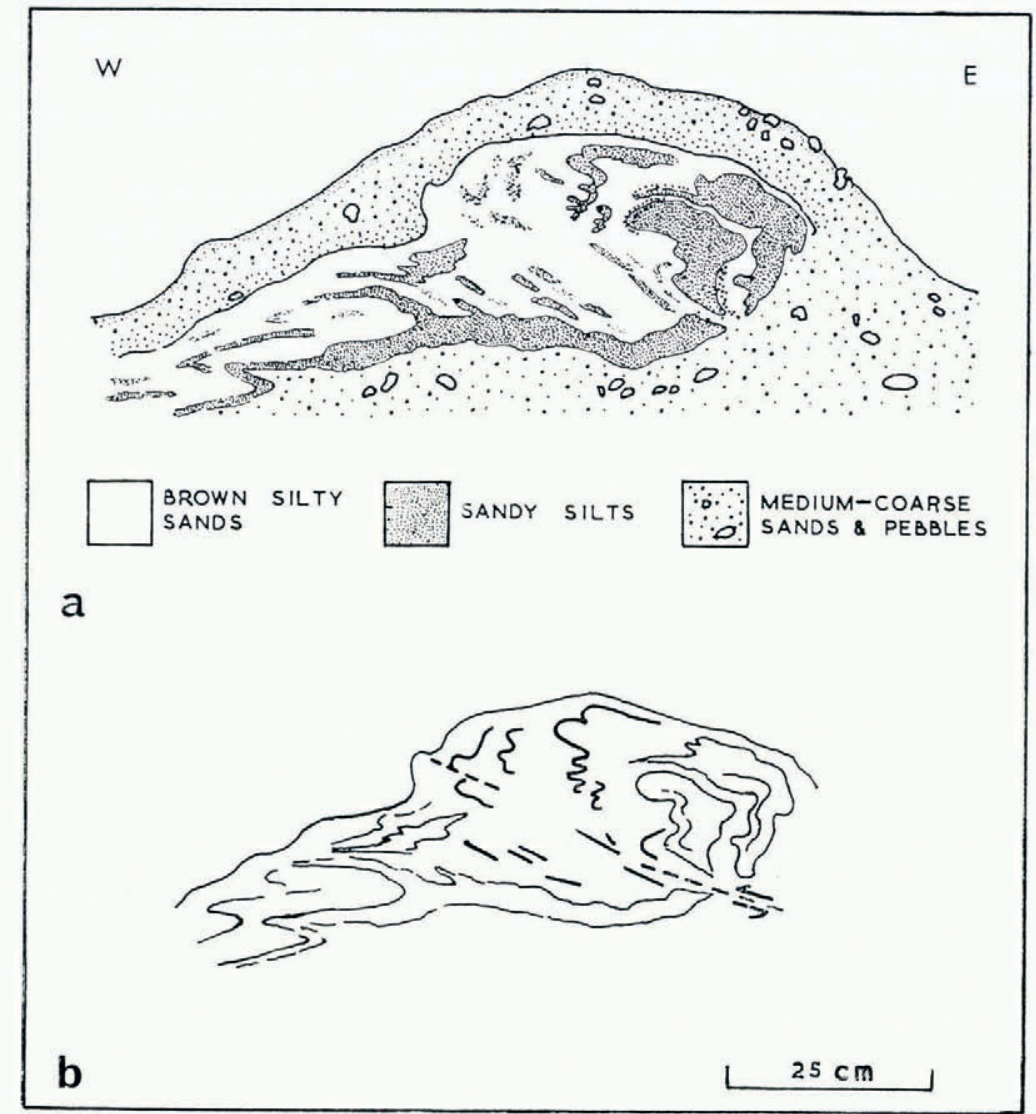

Fig. 6. (a) The sediments which occur within the flute (cf. Fig. 5$) ;(b)$ A schematic representation of the structures observed in Figure 5.

pattern. Below the main thrust there are a number of tight overfolds, also parallel to it. Many of these are sheared out into wisps and streaks. The intensity of deformation decreases to the west, where the folding becomes more open and flat-lying.

These observations suggest that there has been movement away from the eastern margin of the flute. This movement has occurred in two opposite directions, westward into the flute and eastward away from it. In the body of the flute, horizontal compression has resulted from movement of material westward; this is reflected in the anticlinal folding and thrusting, and has also been relieved by the vertical growth of the flute. To the east of the flute the broad overturned folding indicates horizontal compression due to movement eastward, but under conditions of vertical restraint. 


\section{Discussion}

Consider an origin for the flutes in which sediment is squeezed subglacially into a tunnel that exists in the ice in the lee of an obstruction to flow. If this model is correct, it should be possible to correlate the observed deformation of the sediments with the stresses imposed on them by the ice around the tunnel. Weertman (1972, p. 327) has determined the stress distribution at the base of the ice around such a tunnel. There are several different possible solutions which take into account differences in the relative magnitudes of the basal shear stress and the normal stress change at the tunnel wall. In the present case, the tunnel is initially empty and hence at the tunnel wall there will be a change in normal stress of the same order as the ice-overburden pressure; this will almost certainly be greater than the basal shearing stress. Figure 7 shows the stress distribution that is considered applicable under these conditions.

Figure 7 shows that the normal stress exerted on the bed will be greatest beneath the ice near the edge of the tunnel and will decay slowly outwards. On the bed beneath the tunnel, there will be no stress imposed by the ice. It is evident that under this stress distribution the underlying sediments will be squeezed away from the area of high pressure near the tunnel edge towards the areas of lower pressure. This movement will occur in two directions: into the tunnel itself, and away from it.

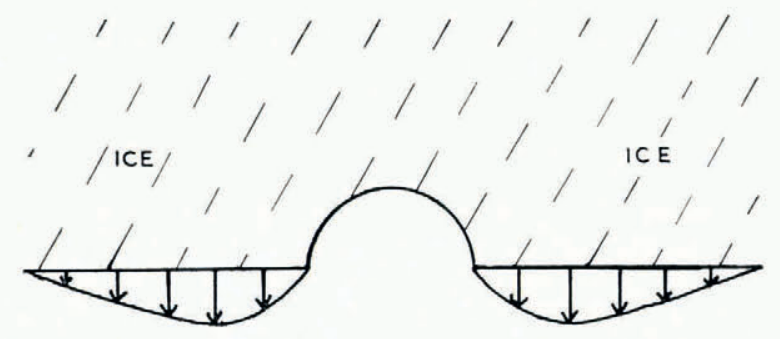

Fig. 7. The distribution of normal stress considered to exist below the ice tunnel discussed here. The magnitude of the stress at a given point is represented by the length of the arrow shown below the ice. Stress is greatest at a point beneath the ice close to the tunnel wall, and from that point it falls in both directions: rapidly, moving towards the tunnel, and more slowly, moving away from it. Beneath the tunnel itself, the normal stress on the bed is zero.

This predicted pattern of deformation is in close agreement with that deduced from the observed structures. The flow of material into the tunnel has produced the folding and thrusting observed in the flute body, while flow away from the tunnel has resulted in the folding observed beneath the flat surface to the east of the flute. Movement away from a central source area is indicated by the direction of overturning of the folds, which is to the west in the flute and to the east under the adjacent flat surface. A corollary of this movement would be the thinning of beds in the source area, and thickening to either side. Figure 4 illustrates some thickening of the sand bed to the right of the scraper handle, where it is folded upwards. Immediately above the scraper the same bed has thinned but the irregular nature of the sediments makes it difficult to demonstrate that this is the result of pressure from the ice. In the flute itself, thickening has resulted mainly from the repeated overfolding of individual beds, several of which can be traced throughout the structure.

Deformation of the sediment would probably be aided by the presence of excess porewater pressure. It is possible that this was generated either by the discharge of melt water through the sediments while they were confined beneath the ice or as a result of compression during the deformation process itself. During the later stages of deformation, the sediments in 
the tunnel were probably confined, since the decrease in dip of the fold-axial planes in the crest of the flute indicates some restriction to vertical movement, which could be the result of the growing flute making contact with the roof of the tunnel. This confinement would assist the generation and maintenance of pore pressure.

The above discussion assumes that the sediments were unfrozen when deformation took place. This cannot be predicted from the observed structures alone, since both frozen and unfrozen sediments may be folded and faulted by stresses of sufficient magnitude and duration. However, considering the relative mechanical properties of glacier ice and frozen sediment, it is known that the sediment will have a creep rate considerably less than that of glacier ice (Hooke and others, 1972). In this event, an empty subglacial tunnel will be closed more rapidly by creep of the surrounding ice than by flow of the underlying frozen sediment. For this reason, it seems likely that deformation of the sediments took place while they were unfrozen. Additionally, the discharge of melt water through the sediments would ensure that they remained unfrozen during summer, while the proximity of the site to the sea suggests that the permafrost surface would be depressed in this area. It may be noted in passing that the structures seem to be unlike those due to freezing, and so the model proposed by Baranowski (1970) does not seem to be applicable in this case.

Finally, we may consider the asymmetry of the folding, which is not expected from the predicted symmetrical stress distribution on either side of the tunnel. It was noted that to the west of the site there were several partially exposed bedrock knobs, on which the glacier was resting. It is possible that the subglacial tunnel itself originates at a similar knob lying farther to the east. The asymmetry of structure within the flute is probably the result of the asymmetric stress distribution expected from this situation, in which to the west of the flute the mass of the glacier is borne locally by this series of bedrock knobs, whereas to the east it is taken directly on the subglacial sediments. As a result, there will be a lower normal stress on the bed to the west of the flute than to the east and hence deformation will be asymmetric. A prediction of this hypothesis is that the deformation on the other flutes to the east should be more symmetric; unfortunately, conditions in the field did not allow the excavation of further pits to test this.

\section{Conclusions}

The observations suggest that the flute was formed when pre-existing sediments were squeezed into a subglacial tunnel and thus that formation was post-depositional. It is likely that the sediments were unfrozen at the time and the deformation may have been aided by excess pore pressure. The observed structures are those that would be expected from the deformation resulting from the theoretical stress distribution imposed on the bed by the ice around such a tunnel.

\section{Acknowledgements}

These observations were made while the authors were members of the Joint Universities Spitsbergen Expedition 1973, and thanks are due to all those who assisted with the expedition. Financial support from the Royal Society, the Natural Environment Research Council (for M.A.P.) and Norfolk County Council (for H.E.) is gratefully acknowledged. Field assistance was given by R. N. Hoffer. Dr G. S. Boulton read the manuscript and made many helpful suggestions.

\section{MS. received 4 February 1974}




\section{REFERENCES}

Baranowski, S. 1970. The origin of fluted moraine at the fronts of contemporary glaciers. Geografiska Annaler, Vol. 52A, No. I, p. 68-75.

Dyson, J. L. 1952. Ice-ridged moraines and their relation to glaciers. American fournal of Science, Vol. 250, No. 3, p. 204-II.

Hooke, R. L., and others. 1972. Creep of ice containing dispersed fine sand, by R. LeB. Hooke, B. B. Dahlin and M. T. Kauper. Journal of Glaciology, Vol. I I, No. 63, p. 327-36.

Hoppe, G., and Schytt, V. 1953. Some observations on fluted moraine surfaces. Geografiska Annaler, Årg. 35, Ht. 2, p. $105^{-1} 5$.

Weertman, J. 1972. General theory of water flow at the base of a glacier or ice sheet. Reviews of Geophysics and Space Physics, Vol. 1o, No. 1, p. 287-333. 